\title{
WACANA KEKERASAN DAN RESISTENSI PEREMPUAN DALAM FILM KARYA SUTRADARA PEREMPUAN
}

\author{
Liestianingsih Dwi Dayanti \\ Departemen Komunikasi Fakultas Ilmu Sosial dan Ilmu Politik \\ Universitas Airlangga \\ Email: liestiad@yahoo.com
}

\begin{abstract}
Mereka Bilang Saya Monyet, a movie by woman director Djenar Maesa Ayu, was a film about women with a different perspective. This movie reveals a discourse on both violence and women's resistance against it. The dimensions shown included psychological, physical, and sexual violence between parents and their child, an adult men with his daughter, and adult men with adult women. Violence appears because of the unbalanced relationship between subject and object. The effects of this violence can take the form of fear, anger, or a feeling of inferiority and unworthiness, and the victim feels encouraged to act on it. Discourse related to gender-based violence is a result of a patriarchal cultural construction. In the film, resistance was portrayed through the victim's suffering, anger, and physical resistance. Women directors perceived these issues from a different perspective. It is not enough to understand violence against women only from the normative perspective of law and social obligation. This issue must be understood by positioning women as the subject (survivor) and recognizing that violence against women is a crime against humanity.
\end{abstract}

Keywords: Women Violence, Resistance, Film and Discourse

\begin{abstract}
ABSTRAK
Film Mereka Bilang Saya Monyet karya sutradara perempuan Djenar Maesa Ayu merupakan film tentang perempuan dengan perspektif berbeda. Film ini mengungkap wacana kekerasan dan resitensi perempuan melawan kekerasan. Dimensi kekerasan yang ditampilkan antara lain kekerasan orang tuaanak, laki-laki dewasa pada anak perempuan dan laki-laki dewasa pada perempuan dewasa berupa kekerasan psikis, fisik, dan seksual. Kekerasan muncul karena relasi yang timpang antara subjek dan objek. Efek kekerasan berupa ketakutan, kemarahan, rasa direndahkan, dilecehkan, tidak berharga dan mendorong korban melakukan perlawanan. Wacana kekerasan berbasis gender merupakan buah dari konstruksi budaya patriarkhi. Resistensi digambarkan dalam bentuk penderitaan pada korban, kemarahan dan perlawanan. Sutradara perempuan melihat persoalan perempuan dengan sudut pandang berbeda. Kekerasan pada perempuan tidak cukup dilihat dari perspektif normatif, hukum, dan kepatutan sosial, ia dilihat dengan menempatkan perempuan sebagai subyek (survivor) serta kekerasan pada perempuan adalah persoalan kejahatan pada kemanusiaan.
\end{abstract}

Kata Kunci: Wacana Kekerasan, Resistensi, Perempuan and Film 


\section{PENGANTAR}

Tumbangnya rezim Orde Baru membawa dampak dalam kebebasan berekspresi pekerja film. Film-film yang pada masa Orde Baru dilarang diproduksi bermunculan dan mendapat respon dari peminat film. Gie, Marsinah, Pasir Berbisik, Berbagi Suami, Arisan, Jamila dan Sang Presiden, Mereka Bilang Saya Monyet serta beberapa film yang bermuatan hal-hal yang selama ini dilarang penguasa, banyak diproduksi. Dari segi jumlah relatif kecil namun cukup menggambarkan adanya perubahan dalam kebebasan berkarya pekerja film. Namun demikian film-film dengan tema mainstream khususnya dalam merepresentasikan perempuan masih banyak dijumpai. Film-film ini menggambarkan perempuan dalam stereotip lemah, tidak rasional, penggoda dan di seberangnya laki-laki dengan stereotip kuat, rasional dan dominan.

Film Mereka Bilang, Saya Monyet! (MBSM) karya sutradara perempuan Djenar Maesa Ayu merupakan film yang keluar dari mainstream tersebut. Film bertema perlawanan perempuan terhadap kekerasan, merupakan film tentang perempuan dengan perspektif perempuan. Film ini menarik diteliti karena tema film ini berbeda dengan filmfilm lain, dalam film ini perempuan diposisikan sebagai subjek (survivor). Dari berbagai studi tentang perempuan di media, hasilnya memperlihatkan representasi perempuan di ranah mainstream seperti berkulit putih, penggoda, lemah, tersubordinat. Vissia Ita Yulianto (2007) meneliti tentang Representasi Pesona Barat Di Indonesia menemukan bahwa, model iklan kosmetik didominasi wajah perempuan Indo, berkulit putih, berhidung mancung.

Kajian tentang Peran Gender dalam Iklan Obat Kuat (Liestianingsih, 2003) menunjukkan perempuan digambarkan sebagai emosional, cengeng, tidak rasional, sensual, berada di wilayah domestik, dan tersubordinat. Demikian juga studi tentang Perempuan dalam Sinetron Komedi (Liestianingsih, 2005) memperlihatkan hasil perempuan dan lakilaki digambarkan tidak proporsional, pe- rempuan bodoh, tunduk, lemah dan lakilaki digambarkan kuat, macho, agresif, pemberani, jantan, mandiri, tegar, berkuasa, pintar, rasional dengan peran sebagai kepala rumah tangga/pemimpin.

Anindita dalam Srinthil, Media Perempuan Multikultural (2007) menyebutkan media mengkategorikan perempuan menurut tubuh dan penampilannya, dan pada dasarnya media adalah perpanjangan industri untuk mendapatkan keuntungan dengan tetap menempatkan perempuan dalam konstruksi tradisional, konstruksi ini dilanggengkan sehingga industri tetap hidup dan meraup untung besar. Di sinilah media meng-anihilisasi secara symbolic yakni menganggap perempuan tidak penting, tidak ada, memarjinalkan, meniadakan, dan mengabaikan.

Mengapa media tidak berani keluar dari mainstream dalam merepresentasikan perempuan? Hal ini berkait dengan pertama, kontrol penguasa: pada masa orde baru kontrol terhadap media termasuk film sangat ketat. Badan Sensor Film (BSF) sebagai lembaga kontrol berperan menyeleksi film yang akan beredar dan salah satunya adalah tidak boleh bertentangan dengan ideologi penguasa pada waktu itu. Kedua, alasan pasar. Pembuat film akan mempertimbangkan faktor profit karenanya mereka akan memproduksi film yang "aman" yang tidak dicekal oleh Badan Sensor Film dan diterima pasar. Karena itu pembuat film akan memproduksi film pada arus utama, yang lebih bisa dijual dan mendatangkan untung dari pada film idealis yang selain akan berhadapan dengan penguasa juga ditolak pasar. Ketiga, pola pikir para para pembuat film yang sarat dengan ideologi patriarkhi. Ideologi ini merasuki para kreator film sehingga dalam melihat relasi perempuan dan laki-laki masih berada pada ranah tradisional. Studi tentang Kesadaran Gender Orang Media (Suryandaru, 2002) mengungkapkan bahwa para kreator, jurnalis, produser, pemilik media masih rendah kesadaran gendernya sehingga produk medianya bias gender. 
Pada era Orde Baru kemunculan sutradara perempuan yang diharapkan mampu menghasilkan karya yang berperspektif perempuan masih sedikit. Krishna Sen (Jurnal Perempuan, 2008) mengatakan kondisi ini disebabkan karena terbatasnya ruang gerak bagi (khususnya sutradara) perempuan dan hal ini memaksa mereka untuk mengadopsi sudut pandang dominan/patriarkis agar bisa bertahan di industri film. Berkait dengan representasi perempuan dalam film (Wood, 2005) menyebutkan bahwa dominasi ideologi patriarkhi terjadi juga dalam film-film Hollywood seperti Fight Club, Armageddon, Gladiator, dengan penggambaran laki-laki serius, percaya diri, mampu, dan berkuasa. Streotip tentang maskulinitas adalah keras, independen, agresif, berani, dan mampu mengontrol emosi dengan baik.

Di sisi lain perempuan digambarkan sebagai penggoda, bekerja di wilayah domestik, mengelola hubungan dengan baik, dan stereotip tentang femininitas adalah setia, hormat, fokus pada rumah dan keluarga, serta subordinat laki-laki. Wood menambahkan di dalam film perempuan digambarkan dengan peran sebagai malaikat, putri, penolong, namun juga sebagai korban. Dengan tampilan yang demikian menurut Wood (2005) peran media sebagai gate keepers (penjaga gawang) dalam menyajikan informasi membentuk persepsi sesuai dengan persepsi yang diinginkan media.

Sebagian besar isi media saat ini (termasuk film) masih pada arus utama dalam mengkonstruksi peran dan nilai-nilai yang bias gender dan hanya sedikit kreator yang mau memproduksi film di luar arus utama. Film Mereka Bilang Saya Monyet merupakan sedikit film yang mengungkap realitas di luar arus utama. Berkait dengan hal tersebut permasalahan penelitian yang menjadi fokus kajian adalah bagaimana wacana kekerasan terhadap perempuan dan perlawanan perempuan terhadap kekerasan dalam film Mereka Bilang Saya Monyet karya Djenar Maesa Ayu. Dengan permasalahan ini tujuan yang ingin dicapai dalam penelitian adalah mendeskripsikan dan meng- eksplorasi wacana kekerasan terhadap perempuan dan resitensi perempuan terhadap kekerasan dalam film Mereka Bilang Saya Monyet karya Djenar Maesa Ayu.

Studi tentang representasi perempuan dalam film relatif masih sedikit dibandingkan dengan studi representasi perempuan di media lain seperti televisi, iklan, majalah/ tabloid, apalagi studi yang secara spesifik menelaah wacana resistensi perempuan dalam film karya sutradara perempuan pasca Orde Baru. Jikapun ditemukan maka sebagian besar studi lebih didominasi tentang representasi perempuan dalam bingkai dikotomi gender femininitas dan maskulinitas. Fokus kajian-kajian tersebut lebih banyak membahas tentang bagaimana media menampilkan peran dan stereotipe gender lakilaki dan perempuan.

Berkait dengan minimnya kajian tentang perempuan dan film menurut Intan Paramadhita (Jurnal Perempuan, 2008) studi ini masih bidang yang asing, dianggap sebagai urusan kalangan tertentu dan direduksi sebagai telaah tentang citra perempuan dan belum pada tataran membedah bagaimana perempuan dalam melawan dan resisten terhadap kemapanan. Pernyataan ini menyiratkan bahwa studi tentang perempuan dalam film masih sebatas melihat bagaimana film menggambarkan konstruksi konvensional media, perempuan di ranah domestik, lemah, tak berdaya, terdominasi dan di seberangnya laki-laki dengan penggambaran di ranah publik, kuat, mendominasi. Hasil studi seperti ini bisa memberikan gambaran bahwa film khususnya film karya sutradara Indonesia sebagian masih berada pada arus utama pada tema dan penokohan, bahkan jika film tersebut hasil karya sutradara perempuan.

Dari jumlah yang terbatas tersebut dengan fokus kajian yang masih berada di arus utama, beberapa kajian menjadi acuan dari studi ini. Kajian Sunarto (2009) tentang representasi kekerasan terhadap perempuan dalam film animasi di televisi menemukan bahwa ideologi gender dominan dalam film anak-anak menggunakan kekekerasan se- 
bagai justifikasi terhadap superioritas lakilaki terhadap perempuan, kekerasan fisik dan seksual sebagai alat laki-laki dalam peran sosial sebagai suami untuk menundukkan perempuan sebagai istri. Dalam film kartun anak-anak di televisi, telah dikonstruksi bagaimana kekerasan menjadi alat untuk menundukkan perempuan, baik kekerasan struktural, maupun personal yang mengindikasikan adanya relasi gender asimetris antara tokoh laki-laki dan perempuan. Temuan Sunarto masih dalam ranah perempuan sebagai korban, tersubordinat, tidak berdaya, dan di seberangnya laki-laki digambarkan sebagai sosok kuat, subjek yang mengendalikan relasi atas perempuan.

Dalam film Armagedon (Wood, 2005) Bruce Willis digambarkan sosok tegas, percaya diri, agresif, berkuasa, dan ia sebagai laki-laki berdarah dingin dalam filmya The Seige. Di sisi lain Julia Robert digambarkan sebagai perempuan genit, menunggu lakilaki baik-baik dalam filmnya Runway Bride, ia juga digambarkan sebagai perempuan yang smart, asertif, seksi, dalam filmnya Erin Brockovich. Pernyataan Wood ini menjelaskan bahwa film-film Hollywood masih berada di arus utama dengan penggambaran peran gender yang dikotomis. Studi Setiawan (2008) tentang representasi perempuan dalam film Indonesia Era Tahun 2000an, menemukan bahwa tampilan perempuan dalam film-film popular dalam wacana ideologi dan praktik sosiokultural dalam masyarakat mengalami pergeseran untuk tidak menyebut perubahan. Hasil temuannya, sebagian film merepresentasi perempuan-perempuan mandiri yang dengan kekuatannya mampu menyelesaikan permasalahan hidup dengan konteks perjuangannya masing-masing. Sekalipun perempuan korban kuasa patriarkhi, namun mereka mampu memaknainya dan dengan kegigihan serta kekuatan mereka bertahan dan meneruskan kehidupan sembari memberi kebaikan kepada orang lain. Ada perlawanan terhadap patriarkhi dengan konsep politik tubuh dan seksualitas.
Beberapa film merepresentasikan perempuan sebagai subjek yg berani berjuang menghadapi permasalahan hidupnya dengan kekuatan fisik dan nalar kreatif meskipun terkadang harus terjerumus perilaku yang dianggap menyimpang dalam masyarakat kita dan tetap membutuhkan kehadiran laki-laki sebagai Dewa Penolong. Temuan Setiawan menyiratkan bahwa filmfilm Indonesia era 2000an dalam merepresentasikan perempuan sebagian masih berada di mainstream walaupun ada beberapa film yang merepresentasi perempuan di luar mainstream yakni perempuan dengan kegigihan dan kekuatannya melawan kuasa patriarkhis sekalipun masih menggunakan politik tubuh.

Husninatul Ghassani (2010) meneliti film Jamila dan Sang Presiden dan hasilnya menujukkan hal yang berbeda dari kebanyakan film Indonesia yang didominasi seksualitas. Film ini mengungkap secara kritis persoalan perdagangan perempuan, pelecehan seksual, dan prostitusi. Kekerasan terhadap perempuan dimanifestasikan dalam berbagai bentuk seperti kekerasan fisik, seksual, ekonomi, perampasan kemerdekaan secara sewenang-wenang dan psikologis. Patriarkisme dan kapitalisme menjadi latar belakang ideologi yang mendominasi tindak kekerasan. Dalam peristiwa kekerasan dengan pelaku laki-laki terdapat konstruksi gender berdasarkan kultur patriarkis tentang sikap laki-laki yang mendominasi karena perannya sebagai subjek dan sikap perempuan yang terdominasi karena perannya sebagai objek. Hal ini kemudian membuat perempuan menjadi kelompok yang rentan mendapat kekerasan. Dalam kapitalisme, kekerasan dijalankan di bawah kekuasaan orang-orang yang mengendalikan sarana-sarana produksi dengan hubungan eksploitatif. Lebih dari itu, film ini juga menunjukkan adanya perlawanan yang dilakukan perempuan, melalui tindakannya membunuh para pelaku kekerasan. 


\section{PEMBAHASAN}

Kekerasan terhadap perempuan merupakan fenomena yang banyak ditemui di masyarakat. Komisi Nasional Anti Kekerasan Terhadap Perempuan (KOMNAS Perempuan, 2011) menyebutkan kasus kekerasan terhadap perempuam di Indonesia pada tahun 2010 mencapai 105.103. Jumlah terbanyak adalah kekerasan di ranah personal sisanya kekerasan di ranah publik dan kekerasan oleh negara (www.komnasperempuan.or.id). Kondisi ini sebuah ironi, karena Indonesia merupakan salah satu negara yang menandatangi Deklarasi Penghapusan Kekerasaan Terhadap Perempuan (CEDAW), Desember 1993 dan tahun 2004 Negara telah mensyahkan Undang-undang No 24 tentang Penghapusan Kekerasan Dalam Rumah Tangga (PKDRT).

Dalam Deklarasi Penghapusan Kekerasan Terhadap Perempuan disebutkan ada 3 lingkup kekerasan terhadap perempuan yakni lingkup domestik (domestic), lingkup masyarakat atau public domain dan kekerasan yang dilakukan oleh negara atau state. Kekerasan terhadap perempuan adalah "setiap tindakan kekerasan berdasarkan perbedaan jenis kelamin yang berakibat kesengsaraan atau penderitaan perempuan secara fisik, seksual, dan psikologis termasuk ancaman tindakan semacam itu, pemaksaan atau perampasan kemerdekaan secara sewenang-wenang, baik yang terjadi di depan umum atau di kehidupan pribadi". Kekerasan terhadap perempuan mencakup tindakan kekerasan secara fisik, seksual, dan psikologis terjadi dalam keluarga, masyarakat luas, kekerasan yang dilakukan dan dibenarkan oleh Negara, di mana pun terjadinya (Elsam, 2010, www.elsam.or.id).

Setiap tindak kekerasan adalah pelanggaran terhadap nilai-nilai kemanusiaan, Kalibonso (2010) menyebutkan dampak kekerasan pada perempuan sangat kompleks selain kesakitan fisik, dan gangguan mental, korban juga memiliki dorongan untuk melakukan tindak bunuh diri. Kekerasan adalah bentuk pemaksaan yang berujud dalam bentuk persuasif maupun fisik atau keduanya. Pemaksaan berarti ada pelecehan terhadap kehendak pihak lain yang mengalami pelecehan hak-haknya secara total, eksistensinya sebagai manusia dengan akal, rasa, kehendak dan integritas tubuhnya tidak dipedulikan lagi (Sunarto, 2009). Kekerasan merupakan tindakan yang terjadi antara dua pihak, subjek (pelaku) dan obyek (korban), di dalamnya ada unsur menguasai dan dikuasai. Bentuk kekerasan dapat berupa kekerasan psikologis, fisik dan gabungan dari keduanya. Dimensi kekerasan berada dalam bentuk (1) kekerasan fisik, psikologis, ekonomi, seksual, spiritual dan fungsional; (2) efek kekerasan (positif dan negatif); (3) partisipan kekerasan (pelaku dan korban); (4) motif kekerasan; dan (5) sumber kekerasan (personal atau struktural) (Sunarto, 2009).

Kekerasan terhadap perempuan sering disebut sebagai kekerasan berbasis gender karena kekerasan yang terjadi akibat adanya relasi berdasar jenis kelamin (gender). Relasi ini menempatkan laki-laki sebagai pihak berkuasa atas yang lain (perempuan), dan akibatnya perempuan berada pada posisi dilemahkan, terkuasai dan tak memiliki kekuasaan untuk melawan. Heise dalam Dzuhayatin (2002) menyebutkan bahwa fenomena kekerasan terhadap perempuan berakar dari persoalan ketimpangan hubungan antara laki-laki dan perempuan dalam kehidupan bermasyarakat. Dalam hal ini kekerasan terhadap perempuan memilik basis secara kultural dan biologis.

Basis biologis berakar dari pandangan umum bahwa seksualitas laki-laki secara alamiah bersifat agresif sedangkan seksualitas perempuan bersifat pasif dan submisif yang menempatkannya pada sex provider. Basis kultural merupakan perluasan dari konstruksi seksualitas perempuan yang berimplikasi pada proses disposisi dan relasi gender yang timpang. Budaya patriarkhi yang phallocentris memberikan privelege lakilaki pada posisi superior dan inferior pada perempuan. Terlahir sebagai perempuan telah menjadikan mereka target mata rantai kekerasan sepanjang hidupnya mulai dari 
mutilasi genital, pembunuhan bayi perempuan, kekurangan gizi sejak masa kanakkanak dan kejahatan seksual di masa dewasa (Espiritu dalam Dzuhayatin, 2002).

Budaya yang demikian menyebabkan minimnya upaya dari perempuan sendiri untuk melawan (resistensi) kekerasan yang dialami bahkan kesadaran bahwa kekerasan adalah pelanggaran nilai-nilai kemanusiaan belum tumbuh di kalangan perempuan. Hanya sedikit perempuan yang melakukan perlawanan atau resistensi terhadap kekerasan, Ayu Utami melakukan perlawanan melalui novelnya Saman serta Larung. (Banita, dalam www.resources.unpad.ac.id.), sutradara film seperti Nia Dinata dengan filmnya Berbagi Suami, Djenar Maesa Ayu dengan filmnya Mereka Bilang Saya Monyet.

Sebagai produk budaya film merupakan refleksi kondisi sosial budaya suatu masyarakat dalam suatu waktu. Di sisi lain film sebagai media massa memiliki kekuatan untuk menanamkan nilai-nilai ideologi atau norma pada penontonnya. Kekuatan media massa dalam menyosialisasikan nilai-nilai tersebut berkait dengan fungsi media massa sebagai piranti untuk menyosialisasikan warisan sosial (Dominick, 1993). Fungsi ini merupakan fungsi yang paling strategis dan menjadi kekuatan media massa dalam mempengaruhi khalayak. Salah satu yang diwariskan adalah ideologi patriarkhi, yang secara masif disebarkan media.

Galliano (2003 dalam Ibrahim, 2007) menyebutkan media dianggap sebagai agen sosialisai gender yang penting dalam keluarga dan masyarakat, media mengungkapkan tentang peran laki-laki dan perempuan dari sudut pandang tertentu. Media menentukan dan mengukuhkan ideologi, "sistem kepercayaan" atau "pandangan dunia" tertentu, menanamkan kesadaran dan mitos tertentu tentang gender. Wood (2005) menguatkan pendapat ini bahwa sajian media dari film anak-anak hingga pornografi mempengaruhi bagaimana pandangan audiens memahami laki-laki dan perempuan, apa yang normal dan benar dalam hubungan antara perempuan dan laki-laki.
Secara historis media merepresentasikan laki-laki dan perempuan dalam stereotip tradisional.

Media massa memiliki kontribusi besar dalam proses konstruksi realitas pada tataran individu. Tampilan media sesungguhnya adalah realitas simbolik hasil karya pekerja media yang dipengaruhi oleh latar belakangnya, realitas simbolik yang ditampilkan ini dimaknai sebagai realitas sesungguhnya oleh audiens. Realitas yang disajikan media menjadi rujukan individu dalam proses diri individu membangun identitas dirinya. Bagi audiens realitas yang dibangun media adalah fakta, dunia objektif. Individu tidak punya daya untuk mengubah dan campur tangan, bahkan individu secara sadar memahami dan menerimanya sebagai sebuah realitas. Thomas Luckman (Baran, 1999) mengatakan terjadi proses sosial melalui tindakan dan interaksinya, dimana individu secara intens menciptakan suatu realitas yang dimiliki. Problemnya realitas yang dibangun media, menjadi realitas yang sesungguhnya bagi individu. Tidak ada proses seleksi pada tataran individu, sehingga berbagai peristiwa yang terjadi ketika diangkat di media menjadi cerita atau wacana yang bermakna adalah realitas yang telah dikonstruksikan.

Film, sebagai media komunikasi massa dalam mengkonstruksi relasi gender berkait dengan siapa kreatornya khusunya sutradara. Dialah yang memiliki peran dalam menentukan apakah karyanya berada pada arus utama dalam melihat relasi ini atau tidak. Peran sutradara dalam mentransfer ide-ide ke dalam bahasa gambar merupakan sentral, dialah yang memegang kendali dalam proses karya film. Ia menerjemahkan bahasa naskah ke dalam "bahasa" suara dan gambar secara spesifik. Naskah (script) divisualisaikan dengan memberikan konsep abstrak ke dalam bentuk yang konkrit atau nyata. Melalui pemilihan shot-shot, sutradara membangun sebuah pandangan atau point of view ke dalam suatu gagasan.

Sutradara berperan dalam menempatkan dan pergerakan kamera, mengarahkan 
akting pemain, pengaturan dialog, dan menentukan latar suara (musik) menjadi satu kesatuan bahasa gambar dan suara. Tanggung jawab struktur dramatis dan alur cerita ke dalam bahasa audio dan visual terletak pada sutradara (www.filmmakers.com). Sutradara merupakan faktor penting dalam produksi sebuah film namun dia tidak dapat bekerja sendiri, dia memerlukan dukungan kru dan para pemain, seorang sutradara "mengendalikan" keseluruhan proses produksi film, dialog, narasi, pencahayaan, pemilihan dan mengarahkan pemain, artistik dan juga editing. Dengan demikian jelas bahwa sutradara menentukan penokohan, alur cerita sebuah film apakah akan berada pada bingkai patriarkhi atau tidak.

Di Indonesia, sineas perempuan jumlahnya sedikit. Krishna Sen (Inside Indonesia No 83/2005) menyebutkan sejak tahun 1926 sampai sebelum reformasi hanya terdapat tiga sutradara perempuan di Indonesia, itu pun karyanya tidak mendapat respon menggembirakan baik secara populer maupun artistik. Pasca reformasi fenomena perempuan di belakang kamera jumlahnya tidak meningkat tajam, namun karya-karya mereka cukup fenomenal. Fenomena ini adalah bagian dari perubahan perfilman Indonesia pasca reformasi. Menurut Sen, pada masa Orde Baru para sutradara dan produser yang bekerja baik laki-laki maupun perempuan tunduk pada pandangan dominan (patriarkhis) di masa itu bahkan mungkin hal ini masih terjadi hingga kini.

Film-film karya sutradara perempuan merupakan film dengan muatan pernyataan politik yakni perempuan sedang mendulum posisi mereka di ranah film Indonesia. Melalui film para sineas perempuan membawa persoalan perempuan kontemporer dipandang dari kacamata "perempuan", hal ini sebuah fenomena yang relatif baru karena pandangan semacam itu juga baru berkembang belakangan ini (Eric Sasono dalam http:/ / rumahfilm.org). Sen (Inside Indonesia, 2005), menyebut pasca Orde Baru muncul para sineas perempuan dengan karyanya yang menyentak dunia perfilman Indonesia seperti Mira Lesmana (produser dan sutradara) dengan karyanya "Sherina", Nan T Achnas (penulis dan sutradara film Pasir Berbisik) dan Nia Dinata (sutradara Ca-baukan dan Arisan).

Untuk menganalisis wacana kekerasan dan resistensi perempuan dalam film MBSM digunakan analisis wacana kritis (CDA). Metode ini dipilih karena metode ini dalam mengungkap suatu wacana tidak hanya menganalisis aspek kebahasaan namun juga menghubungkan antara bahasa dan konteks, yaitu bahwa bahasa digunakan untuk tujuan dan praktik tertentu termasuk di dalamnya praktik kekuasaan. Analisis wacana kritis melihat wacana -pemakaian bahasa dalam tutur dan tulisan- sebagai bentuk dari praktik sosial. Dengan demikian, bisa ditampilkan efek ideologi, memproduksi dan mereproduksi hubungan kekuasan yang tidak imbang antara kelas sosial, laki-laki dan perempuan, kelompok mayoritas dan minoritas. Melalui wacana ketimpangan dalam kehidupan sosial sebagai suatu kewajaran.

Udasmoro (2009), CDA melihat fenomena-fenomena ketimpangan, ketidakseimbangan, ketidakadilan ataupun keberpihakan dalam suatu fenomena yang ditampilkan. Topik-topik yang seringkali diangkat adalah marginalisasi terhadap kelompok minoritas, persoalan seksisme, rasisme, dikriminasi, kemiskinan dan aspek-aspek ketimpangan kelas maupun gender. Bentukbentuk penelitian analitis terhadap wacana ini kemudian mengkaji kasus-kasus dominasi, eksploitasi, ketidakadilan yang terlihat dari text (tulisan) dan talk (ujaran) dalam konteks sosial politik. Pendekatan ini berargumen bahwa bahasa bukanlah sekedar produk netral yang hanya dilihat secara struktural unsur-unsur di dalamnya, dalam bahasa, ada nilai-nilai kekuasaan serta hubungan kekuasaan yang bersifat ideologis dan historis. Pemroduksian bahasa pun bersifat kultural.

Penggunaan bahasa, wacana, interaksi verbal dan komunikasi dianggap hanya merupakan level mikro. Sementara itu, po- 
wer, dominasi, ketidakadilan dalam realita sosial merupakan level makro dari analisis. CDA berfungsi memediasi antara teks dan masyarakat. Analisis diskursif bersifat interpretatif dan explanatory dengan melihat sumber-sumber fokus pada aspek-aspek power, dominasi, hegemoni, ideologi, kelas, gender, ras, diskriminasi, kepentingan, reproduksi, sosial struktur atau aturan sosial. Analisis wacana kritis digunakan untuk mengungkap hal yang tersembunyi dari subjek (kreator) film dalam menyampaikan suatu pernyataan, pemikiran, ide, perasaan dan kepercayaannya, bagaimana hubungan antara kekuasan dalam pembentukan subjek dan berbagai tindakan representasi.

Fairclough (1992) membangun model analisis wacana yang mempunyai kontribusi dalam analisis sosial dan budaya dengan mengkombinasikan tradisi analisis tekstual dengan konteks masyarakat yang lebih luas. Menurut Fairclough sebuah teks tidak dapat lepas dari konteks sosial masyarakat. Karenanya model Fairclough sering disebut dengan model perubahan sosial, ia mengintegrasikan secara bersama analisis wacana yang didasarkan pada linguistik, pemahaman sosial dan politik dan secara umum diintegrasikan pada perubahan sosial.

Bahasa menurut Fairclough adalah praktik sosial, refleksi individu mereflekasikan sesuatu. Bahasa sebagai praktik sosial mengandung implikasi, pertama, wacana dibentuk dari tindakan, seseorang menggunakan bahasa sebagai sebuah tindakan pada dunia khususnya sebagai bentuk representasi ketika melihat dunia realita. Kedua, model ini membawa implikasi adanya hubungan timbal balik antara wacana dan struktur sosial dan berkait dengan ini wacana terbagi oleh struktur sosial, kelas, dan relasi sosial lain yang dihubungkan dengan relasi spesifik dari institusi tertentu seperti pada buku, pendidikan, sosial dan klasifikasi (Fairclough, 1992).

Untuk menganalisis wacana kekerasan dan resitensi perempuan dalam film karya sutradra perempuan, film yang akan diteliti adalah film "Mereka Bilang Saya Monyet" karya Djenar Maesa Ayu. Alasan dipilihnya film MBSM karena film ini masih belum banyak dikaji khususnya kajian tentang wacana kekerasan dan resistensi perempuan. Secara ringkas film MBSM mengisahkan tokoh Ajeng, perempuan muda, modern dengan masa kecil yang kelam. Film bercerita dengan gaya flash back dimulai dari tampilan sosok Ajeng di kamarnya di sebuah apartemen. Bekerja sebagai penulis cerita anak, ia tinggal terpisah dengan ibunya meski mereka tinggal di satu kota. Ia memiliki teman kencan bernama Asmoro, seorang laki-laki yang telah beristri. Asmoro juga bertindak sebagai mentornya dalam menulis cerita. Sejak kecil kedua orang tua Ajeng berpisah. Ibunya berpacaran dengan seorang laki-laki. Saat kanak-kanak ia mengalami kekerasan seksual dari pacar ibunya secara berulang. Kekerasan lain diperoleh dari Ibunya berupa kekerasan verbal dan fisik.

Hasil kajian terhadap film "Mereka Bilang Saya Monyet" antara lain dimensi bentuk kekerasn dalam film MBSM menampilkan kekerasan fisik, psikologis, ekonomi, seksual dan dimensi partisipan menampilkan relasi antara ibu dan anak perempuan, lakilaki dan anak perempuan, laki-laki dan perempuan. Dari dimensi efek kekerasan menimbulkan efek negatif berupa trauma dan efek positif berupa resistensi terhadap kekerasan. Motif kekerasan yang dapat dianalisis motif beragam, dan dimensi sumber kekerasan personal dan struktural.

\section{Wacana Kekerasan Orang Tua terhadap Anak dan Resistensi Anak terhadap Kekerasan}

Wacana kekerasan orang tua terhadap anak ditampakkan pada awal film dengan adegan Ajeng dewasa menulis di laptop: $I b u$ saya....adegan ini dilanjut dengan flash back adegan masa kecil Ajeng yang menulis: $I b u$ saya monyet... di halaman buku sekolah, pada saat Ajeng menulis, Ibu Ajeng berdiri di belakang dan dengan wajah marah ia mendorong kepala Ajeng hingga membentur meja. Visualisai posisi Ajeng kecil duduk di meja dan ibunya berdiri di belakang 
Ajeng, dapat dimaknai bahwa relasi antara Ajeng dan Ibunya adalah relasi yang timpang, ibu berada pada posisi lebih tinggi, dominan dan berkuasa atas tubuh Ajeng, dan di sisi lain Ajeng yang lemah, dengan ekspresi wajah ketakutan, menunjukkan tidak mempunyai kekuatan apa-apa untuk melakukan perlawanan. Namun dari teks yang ditulis Ajeng "Ibu saya monyet" menunjukkan perlawanan Ajeng kecil terhadap "kekuatan" Ibunya. Adegan ini merupakan awal penggambaran kekerasankekerasan yang dialami Ajeng (perempuan) dan perlawanan-perlawanan yang dilakukan terhadap orang tuanya (Ibu).

Adegan lain yang menggambarkan kuasa atas tubuh anak oleh orang tua direpresentasi melalui adegan berikut, Ajeng tidur di samping pacarnya Asmoro, Ajeng menerima telpon dari Mommynya, terjadi dialog antara Ajeng dan Mommy.

(A : Ajeng, M: Mommy)

A : Morning Mommy,

$\mathrm{M}$ : Morning Jeng, baru bangun?

A : Udah dari tadi, ini leher sedang tidak sehat

M : Hah banyakan ngrokok! gimana mau sehat kalo masih ngrokok kayak kereta api, mau kena kanker?

A : Ini udah ngurangi mam, ini cuma 3 batang

M : Jangan bohong, Jumat malem pasti kamu dugem ga mungkin cuma ngrokok 3 batang (hening)

M : Jeng, kok diam

A : Ya Mam

$\mathrm{M}$ : Lemes amat kurang vitamin tuh, mau dibawain lagi?

A : Ga usah kemarin masih ada kok

$\mathrm{M}:$ Buah?

A : Kan masih ada

M : Lho kan udah lama, ga busuk tu

A : Kan ada kulkas

M : Ya udah jangan lupa sarapan, kurangi alkohol sama rokoknya

Dari teks visual dan dialog terlihat bahwa dominasi Ibu terhadap kehidupan Ajeng dewasa sangat kuat. Padahal sebagai seorang perempuan yang hidup di kota besar Ajeng memiliki kebebasan untuk menentukan hidupnya. Penggunaan apartemen dengan interior tempat tidur, dapur, ruang tamu mewah sebagai setting tempat menunjukkan bahwa Ajeng adalah figur perempuan perkotaan kelas menengah yang sukses dan bebas mengatur hidupnya. Ia merepresentasi perempuan muda di kota besar, bebas, mandiri, dari kelompok kelas menengah atas, menikmati kehidupan malam di diskotik, minum dan merokok, kebebasan bergaul dengan teman perempuan dan lakilaki yang disukai. Namun pada saat berada di posisi sebagai anak ia tersubordinat orang tua (ibu).

Kekerasan dan relasi tidak seimbang tergambar dalam adegan Ajeng kecil yang tertangkap Mommynya ketika memuntahkan makanan di closet. Mommynya memaksa Ajeng mengambil dan memakan kembali muntahan makanan yang ada di closet.

M : Mommy, A : Ajeng

$\mathrm{M}$ : Kamu muntahin lagi sayurnya?

A : diam

M : Kalo ditanya jawab yang bener dong, sini kamu, ini apa? Kenapa sih kamu, Mommy bener-bener ga ngerti. Tiap detik kamu lihat dengan mata kepala kamu sendiri Bapak kamu ga kasih apa2. Mommy yang kerja banting tulang siang malam agar kamu bisa makan! Sekarang Mommy mau dengar, apa alasan kamu? ga suka makan sayur?

A : mengangguk

M : Oh ya jadi karena alasan ga suka kamu tega bohongi Mommy. Terus kenapa kamu muntahin? kenapa Mommy terus2an kamu bohongi, sudah mami bilang berkali-kali Mommy ga suka dibohongi. Bohong itu bukan berarti takut, tapi justru berani. Kamu senang melawan? Kenapa makannya selalu dimuntahin? ya udah kalo ga mau jawab. Jadi benar ya kamu suka sama makannya? ga ada masalah kan? ya udah makan!! makan!! dasar bapak 
bangsat, anak keturunan bangsat, maunya diperlakuin seperti binantang, dasar bukan manusia, anak ga mau diuntung.

Visualisai adegan kekerasan tersebut merupakan kekerasan psikis dan fisik, dengan dimensi partisipan pelaku (subyek) memiliki posisi dominan dari korban (obyek). Motif kekerasan yang dilakukan adalah pemaksaan kehendak, menempatkan anak pada posisi subordinat. Kekerasan ini merupakan kekerasan personal, kekerasan yang dilakukan oleh seorang pelaku kepada korban secara langsung. Efek yang ditimbulkan adalah ketakutan, kemarahan korban, dan rasa direndahkan, dilecehkan dan tidak berharga pada diri korban.

Berkait dengan realitas sosial maka wacana ini merupakan wacana relasi kuasa antara orang tua dan anak dalam konteks budaya Indonesia yang memposisikan orang tua berkuasa atas anak sampai kapanpun usia anak. Anak (Ajeng) sekalipun telah dewasa, mandiri sebagai individu ia tetaplah diposisikan sebagai anak yang harus tunduk patuh pada orang tua. Orang tua memiliki kewenangan, kekuasaan untuk mendominasi, mengatur, mengendalikan anak.

Tokoh Ibu dalam konteks ini diletakan sebagai sosok orang tua yang dalam konteks budaya Indonesia (Timur) dia adalah pemilik kebenaran, memiliki pengetahuan yang oleh Foucault, disebutkan bahwa kekuasaan selalu terartikulasikan melalui pengetahuan dan sebaliknya pengetahuan selalu punya efek kuasa. Tidak ada pengetahuan tanpa kuasa dan tidak ada kuasa tanpa pengetahuan. Kekuasaan bertanggung jawab atas penciptaan dunia sosial kita dan atas caracara tertentu dalam membicarakan dan membentuk dunia ini, dengan demikian mendorong lahirnya hubungan cara-cara alternatif pembicaraan dan keberadaan atas sesuatu. Dari relasi yang terbangun antara Ajeng dan Ibunya -selain karena kultur Indonesia yang menempatkan orang tua selalu benar- kekuasan itu ada karena Ibu memiliki pengetahuan tentang hidup sehat, hidup yang baik, hidup yang benar.
Kekerasan orang tua pada anak terlihat pada visualisasi adegan ketika cerpen Ajeng berjudul "Lintah" dimuat di sebuah harian terkenal. Pemuatan cerpen ini sebuah prestasi bagi Ajeng karena selama ini dia adalah penulis cerita anak dan tidak mudah menembus harian tersebut. Pemuatan cerpen "Lintah" ini memicu kemarahan ibunya yang menganggap bahwa isi cerita itu adalah kisah Ajeng dan Ibunya.

Mommy: Puas setelah usaha Mommy untuk berubah, kamu pendendam! Kenapa dendam kamu cuma buat Mommy,apa pun yang mommy lakukan cuma buat kamu dan paling tidak sebagai orang tua tidak lepas tanggung jawab pada anak sementara bapak kamu, setelah kejadian itu kamu sempat tinggal bersama dia kamu lihat sendiri bapak kamu cuma ngurusi perempuan, perempuan, kalo tidak dengan gampangnya bapak kamu ninggalin kita, ga mungkin ada kejadian ini ga mungkin!

Dialog ini divisualisasi dengan Ibu berdiri, Ajeng duduk. Adegan ini menempatkan Ajeng pada posisi sebagai anak tidak berdaya, lemah, diam, sementara Mommynya mendominasi, dengan suara geram, marah dan emosional. Ajeng walau telah dewasa dan punya kehidupan sendiri masih dikendalikan oleh Mommynya. Di sisi lain melalui Cerpen yang ditulis, Ajeng menyampaikan kemarahan, perlawanan terhadap kekerasan yang dialaminya semasa kecil yakni kekerasan seksual yang dilakukan oleh pacar Mommynya, bagi Ajeng kekerasan itu terjadi karena ibunya membiarkan lintah berada dalam rumahnya, ibunyalah yang mengundang lintah masuk ke dalam rumah dan merusak hidupnya. Bagi Mommynya cerpen ini bentuk dendam Ajeng pada ibunya.

Relasi kuasa yang timpang antara orang tua dan anak, digambarkan dalam film ini berlatar belakang masyarakat modern, de- 
ngan simbol-simbol seperti apartemen, interior mewah, kehidupan malam dan perempuan mandiri yang identik dengan kebebasan. Dengan penggambaran ini maka realitas sosial yang diwacanakan film ini adalah relasi orang tua dan anak dalam kultur modern (melalui tokoh Ajeng), tidak mengalami perubahan. Kehidupan kota besar yang identik dengan kemajuan masih menyisakan kultur dan struktur sosial, di mana dominasi orang tua terhadap anak sesuatu yang masih berlangsung. Bahkan wacana ini menggambarkan realitas sosial tentang kekerasan pada anak yang dapat terjadi dimana-mana, baik pada masyarakat kelompok bawah, menengah bahkan atas. Pelakunya bisa ayah, ibu, kakak, kakek, dan orang-orang terdekat.

Dalam konteks sosial masyarakat Indonesia kekerasan pada anak merupakan realitas yang banyak ditemui namun demikian ia merupakan fenomena gunung es, jumlahnya besar namun tidak mudah diungkap karena dalam konteks budaya Indonesia kekerasan pada anak sering dianggap sebagai masalah privat dan tidak dapat diintervensi oleh orang lain. Realitas sosial yang dapat disampaikan adalah bahwa anak berada pada posisi tawar yang sangat lemah. Anak menjadi sasaran kemarahan dan kekerasan orang tua. Anak dianggap sebagai property (barang) milik orang tua dan orang tua punya hak penuh atas tubuh dan jiwa anak.

\section{Wacana Kekerasan dan Resistensi Perempuan Terhadap Kekerasan}

Simbolisasi kekerasan yang dilakukan laki-laki terhadap perempuan menggunakan lintah, binatang melata yang menghisap darah manusia, ia tidak akan berhenti menghisap sebelum kenyang. Simbolisasi ini sangat menarik, halus sehingga film yang menceritakan kekerasan seksual tidak mengesankan sebagai film vulgar. Namun demikian simbolisasi ini membawa penonton pada gambaran bahwa kekerasan seksual yang disampaikan dalam film ini "mengerikan". Kekerasan seksual menghisap seluruh tubuh dan hidup korbannya. Ajeng mengalami kekerasan seksual dari pacar Mommynya di usia anak-anak. Dimensi bentuk kekerasan Pacar Mommy terhadap Ajeng adalah kekerasan psikis, fisik dan seksual. Dimensi partisipan adalah laki-laki dewasa dan anak perempuan, dimensi motif adalah dominasi gender dan efek yang ditimbulkan negatif berupa trauma, sumber kekerasan personal, kekerasan dilakukan langsung oleh pelaku terhadap korban.

Representasi kekerasan ditampilkan melalui adegan lintah melata di paha, punggung dan air bak mandi. Social code yang ditampakan adalah wajah ketakutan Ajeng kecil dan wajah kemenangan dan berkuasa pada tokoh pacar Mommy. Realitas yang ditampilkan bahwa tokoh pacar Mommy menempatkan Ajeng (perempuan) sebagai obyek seks. Ekspresi wajah Ajeng kecil yang ketakutan, jijik namun tidak mampu melawan sementara laki-laki pelaku digambarkan senang dan mendapat kepuasan atas korban, memperlihatkan bahwa dalam realitas sosial kekerasan gender dilatarbelakangi pada kultur patriarkhi bahwa laki-laki memiliki power atau kekuasaan pada tubuh perempuan. Foucault yang dikutip Prabasmoro (2006) menyebutkan bahwa wacana seksualitas tidak mungkin dilepaskan dari wacana kekuasaan dan pengetahuan, di dalamnya termasuk cara kerja budaya yang dikonstruksi untuk melanggengkan tatanan kekuasan yang patriarkhal. Dalam kajian ini representasi tokoh laki-laki sebagai pihak yang memiliki kuasa atas tubuh perempuan dan perempuan sebagai obyek kuasa tersebut.

Wacana kekerasan yang disampaikan dalam film ini adalah wacana kekerasan berbasis gender sebagai buah dari konstruksi budaya patriarkhi, dan seolah-olah kekerasan semacam ini merupakan hal wajar karena dalam realitas sosial kekerasan berbasis gender sesungguhnya amat banyak terjadi di masyarakat namun kekerasan seperti ini sulit diungkap karena kultur menempatkan kekerasan gender dianggap sebagai sesuatu yang privat, terjadi di wilayah 
domestik sehingga tidak layak diungkap. Ada anggapan bahwa kekerasan seksual berbasis gender jika diungkap akan menimbulkan sanksi sosial dari masyarakat, walau sesungguhnya korban sangat menderita. Ada ketidakadilan, korban yang seharusnya mendapat perlindungan, keadilan justru diposisikan sebagai penyebab aib keluarga, bahkan mendapat sanksi sosial.

Jika dalam film-film mainstream, kekerasan berbasis gender membiarkan korban sebagi tokoh yang kalah, lemah dan tak berdaya, dalam film MBSM, sutradara menempatkan sosok Ajeng sebagai subjek yang melakukan perlawanan melalui adegan Ajeng menulis cerpen berikut:

Ibu saya memelihara seekor lintah, lintah itu dibuatkan sebuah kandang, yang mirip seperti rumah boneka berlantai dua, lengkap dengan kamar tidur, ruang makan, ruang tamu, kamar mandi, yang ditempatkan tepat di sebelah kamar ibu. Saya selalu merengek kepada ibu agar ia mengganti lintah dengan hewan peliharaan lain. Namun ibu bersikeras mempertahankan lintah sebagai hewan peliharaan tunggal di rumah kami.

Melalui teks ini sutradara menempatkan Ajeng sebagai perempuan yang berani melaukkan perlawanan terhadap kekerasan yang dialaminya, dan tergambar bagaimana kekerasan berdampak luar biasa berupa trauma psikologis sepanjang hidup. Keinginan Ajeng agar Ibunya membuang, menyingkirkan binatang paiaran lintah adalah refleksi dari kemarahan Ajeng atas kekerasan yang dialaminya. Sutradara menyodorkan pada penonton bahwa kekerasan yang dialami perempuan menimbulkan penderitaan dan luka, teks ini menyuarakan rasa sakit, kemarahan dan perlawanan perempuan atas ketidakadilan yang dialami.

Teks lain yang menggambarkan perlawanan Ajeng terhadap kekerasan dan ketidakadilan, digambarkan dalam visualisasi pada saat Ajeng dewasa mendikusikan tentang cerpennya berjudul "Lintah" dengan Asmoro. Asmoro menilai tulisan Ajeng tidak layak. Ajeng lebih baik menulis cerita anak daripada cerita dewasa. Mendengar komentar Asmoro, Ajeng sangat marah. Berikut dialog Ajeng dan Asmoro.

Asmoro: Sedikit berlebihan ya, ini benerbener pernah kamu alami?

Ajeng : Ya enggak lah

As : Ini seperti menulis cerita anakanak, banyak imajinsi, terlalu hiperbola

Aj : Fiksi itu imajinasi

As : Ya oke coba kamu lihat tokoh utama, perempuan ini dilecehkan, diperkosa tetapi tidak pernah melawan

Aj : Kamu ini tolol, ga pernah lihat tivi, baca koran. Berapa banyak korban perkosaan yang hanya terima nasib, berapa banyak yang ingin bunuh diri. Mereka sudah kehilangan semuanya, harga diri, kepercayaan diri, boro-boro mau melawan, semangat hidupnya hilang dan ini realitas.

As : Tapi negara kita negara hukum, kenapa tidak seret bajingan pemerkosanya ke polisi. Dudukin di meja pengadilan

$\mathrm{Aj} \quad$ : Uhh, kamu tu buta apa buta? Sejak kapan hukum di negara ini berlaku? Jangankan lapor polisi, orang keluarga yang harusnya belain aja malah neken-neken korban dengan malu lah, aib keluargalah, terus takut kalo anaknyanya ga perawan ga ada yang ngawinilah, taiklah

As : aku ga maksud membuat marah, aku kan diminta kasih pendapat, tulisanmu ini terlalu kelam, kelam sah-sah saja. tapi harus ada perubahan dalam cerita, ada penyelesaian tidak ngambang seperti ini ga dangkal kayak gini

$\mathrm{Aj} \quad$ : emangnya dalam realitas harus ada penyelesaian 
As : justru itu, pembaca butuh penyelesaian. saya yakin pembaca lebih suka cerita anak-anak karyamu.

Teks dalam dialog tersebut menunjukkan bahwa Asmoro (laki-laki) menganggap perkosaan sebagai sesuatu yang sederhana, dapat diselesaikan dengan mudah, melalui jalur hukum maka persoalan akan beres. Sementara Ajeng (perempuan) melihat perkosaan sebagai sesuatu yang sangat kompleks, menyangkut penderitaan, harga diri, kepercayaan dan ketidakberdayaan.

Wacana dalam film ini adalah bahwa korban perkosaan mengalami penderitaan luar biasa, selain dampak fisik dan psikologis ia juga mengalami dampak sosial yang justru dilakukan oleh keluarganya. Keluarga yang seharusnya membela justru menekan korban karena perkosaan menimbulkan malu dan aib keluarga, bahkan kehilangan keperawanan sebagai nilai lebih tinggi dari penderitaan karena perkosaan. Realitas sosial menunjukkan bahwa masyarakat memiliki norma-norma bahwa perempuan korban perkosaan akan membawa petaka bagi keluarga, menimbulkan aib dan karena itu kasus perkosaan terutama jika pelakunya adalah anggota keluarga korban akan disembunyikan.

Wacana yang dibangun adalah bahwa perempuan yang mengalami kekerasan tidak dapat menghapus, melupakan peristiwa itu kapanpun. Penderitaan itu akan muncul kembali dalam segala wujud. Teks tentang resistensi Ajeng terhadap ketidakadilan, kekerasan dan dominasi laki-laki di-

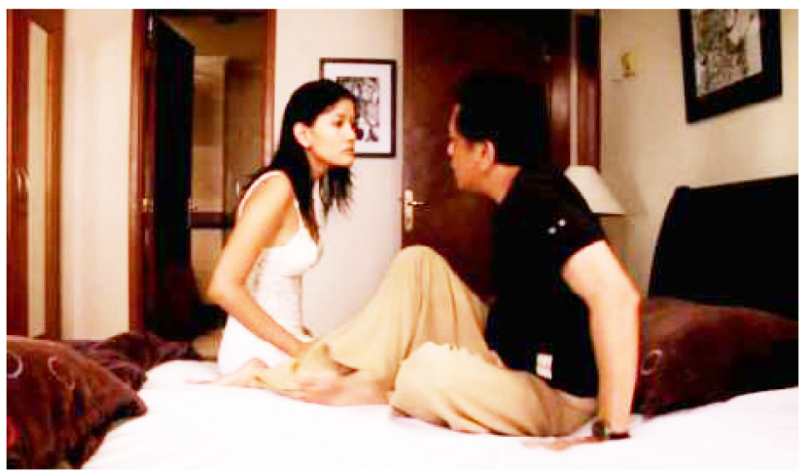

gambarkan melalui adegan seperti terlihat pada gambar 1 .

Adegan diawali saat Ajeng usai menerima tamu laki-laki. Ajeng tidak hanya bekerja sebagai penulis cerita anak namun dia juga bekerja sebagai PSK. Setelah ia tidur dengan laki-laki yang membayarnya, Asmoro datang. Ajeng telah siap tidur dengan Asmoro namun ternyata Asmoro menolak.

Ajeng (Aj), Asmoro (As)

As : puas!

Aj : udah tahu dia ga bisa memuaskan saya masih nanya, tenang aja Cin kan cuma kamu yang bisa memuaskan aku

As : sudahlah!

$\mathrm{Aj}$ : jangan bilang kamu cemburu, belajar dari bini ya, catet ya, saya sudah berhubungan sama dia sebelum aku ketemu kamu, sama aja dengan kamu,kamu sudah punya bini sebelum ketemu aku lagian kamu tahu aku ga suka sama dia

As : lagian kalau kamu ga suka kenapa mau ditidurin?

Aj : kamu sendiri bilang ga cinta ma bini kenapa mau ditidurin? kalo saya sih jelas, saya harus makan, belanja, bayar apartemen buat kita ngewek, kurang enak apasih dapat cewek gratisan kayak saya, hari gini mana ada cewek yang mau ama cowok kere, cuma begobegonya saya ma bini kamu aja.

As : gue pikir kamu dah berubah

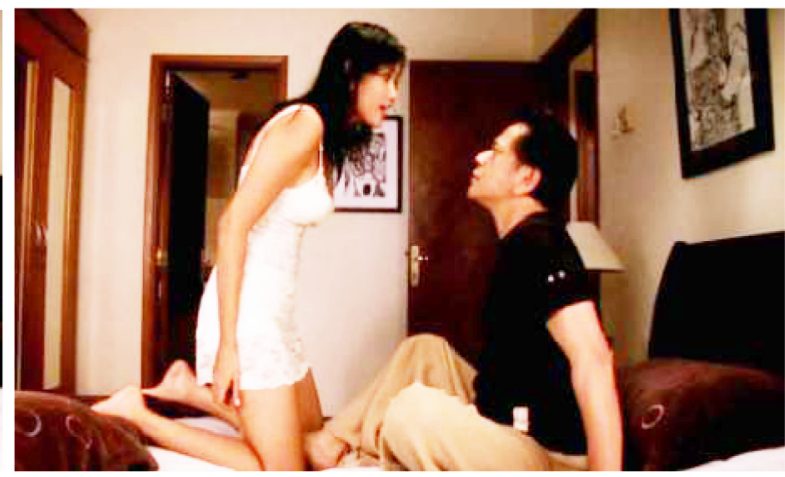

Gambar 1.

Adegan dan percakapan antara Ajeng dan Asmoro 
Aj : berubah? untuk apa? emang kenapa saya?

As : udahalah, susah ngomong sama orang yang kerjanya menbohongi diri sendiri

Aj : ngomong apa sih kamu tentang saya, tahu apa kamu tentang hidup saya? ga ada di dunia ini yang tahu tentang hidup saya, ibu saya, bapak saya, temen-temen saya apalagi kamu

Adegan ini memperlihatkan Ajeng yang mengendalikan dialog, posisi tubuh Ajeng lebih tinggi dari Asmoro, dengan posisi tubuh miring dan mendesak Asmoro menunjukkan Ajeng marah dan menekan Asmoro. Dari dialog terlihat bahwa Ajeng sangat marah dan melawan pendapat Asmoro tentang bagaimana seharusnya perempuan berpasangan. Represenasi yang disampaikan bahwa kekerasan pada perempuan baik semasa dia anak-anak atau dewasa akan membawa dampak luar biasa. Tidak mudah menjelaskan pada orang lain apa yang dirasakan perempuan. Bahkan Ibu dan Bapaknya saja tidak akan bisa mengerti apa yang dirasakan perempuan. Selain itu sutradara ingin menyampaikan bahwa ada dominasi laki-laki pada relasi antara Ajeng dan Asmoro, ketika Ajeng mendua (memiliki pasangan lain) Asmoro cemburu dan tidak dapat menerima perempuan memiliki pasangan lebih dari satu. Ada ketidakadilan yang memposisikan bahwa laki-laki boleh memiliki lebih dari satu pasangan sementara perempuan tidak.

Ajeng merepresentasikan perlakuan yang tidak adil. Ungkapan Ajeng pada Asmoro tentang hubungan Asmoro dengan istrinya "lagian kamu kalau ga suka kenapa mau ditidurin", menunjukkan suatu hubungan yang tidak seimbang antara laki-laki dan perempuan, jika perempuan dilarang tidur dengan laki-laki lain walau mereka tidak terikat sebagai suami-istri, sementara laki-laki boleh tidur dengan perempuan lain. Selain itu ungkapan Ajeng yang disampaikan dengan suara tinggi, wajah marah dan mata melotot "kurang enak apa sih dapat cewek gratisan kayak saya, hari gini mana ada cewek yang mau ama cowok kere, cuma begobegonya saya ma bini kamu aja", menunjukkan bahwa Ajeng lah yang selama ini mengeluarkan uang dalam jalinan hubungan dengan Asmoro (laki-laki), namun ketika laki-laki itu bermaksud mengatur hidupnya Ajeng marah tidak bisa menerima hal itu.

Dalam realitas sosial, laki-lakilah yang berkuasa atas tubuh perempuan. Laki-laki boleh memiliki hubungan dengan banyak perempuan, sementara perempuan tidak pantas memiliki pasangan laki-laki lebih dari satu. Selain itu laki-lakilah yang mengatur hidup perempuan sekalipun ia tidak memiliki kemampuan finansial. Dalam konteks ini ada ketidakadilan gender, ada ketimpangan, yang menempatkan perempuan sebagai pihak yang tersubordinat. Realitas sosial yang dapat dijumpai di masyarakat bahwa lakilaki yang memiliki banyak pasangan justru dianggap macho, hal yang wajar.

Perlawanan Ajeng terhadap ketimpangan terlihat dari ungakapan: "ngomong apa sih kamu tentang saya, tahu apa kamu tentang hidup saya? ga ada di dunia ini yang tahu tentang hidup saya, ibu saya, bapak saya, tementemen saya apalagi kamu!" Dialog ini merefleksikan bagaimana penderitaan Ajeng dan pengalaman masa kecilnya, kekerasan yang dialami dari ibunya, dari pacar Mommynya tidak ada satupun yang dapat mengerti. Ajeng sebagai simbol perempuan yang menderita karena kekerasan yang dialami di masa lalunya. Ucapan ini bentuk resistensinya terhadap kekerasan dan pengalamannya. Dalam konteks ini, realitas sosial memperlihatkan hanya sedikit perempuan yang mampu mengungkapkan perlawanan semacam ini. Sebagian besar perempuan akan menyembunyikan, jangankan melawan, membuka diri mengungkapkan pengalaman saja sebagai sesuatu yang sulit. Stigma masyarakat terhadap perempuan yang mengalami kekerasan masih terus terjadi, perempuan bahkan dikucilkan, dianggap membawa aib dan mendapat sanksi sosial.

Di sisi lain, negara yang seharusnya memberikan perlindungan kadang justru 
melanggengkan terjadinya kekerasan. Sekalipun Negara telah menandatangani konvensi penghapusan kekerasan terhadapan perempuan (CEDAW) dan diterbitkannya Undang-undang Penghapusan Kekerasan dalam Rumah Tangga (PKDRT) namun pemahaman masyarakat dan bahkan penegak hukum akan pentingnya perlindungan pada perempuan dan anak masih belum memadai.

\section{SIMPULAN}

Berangkat dari keinginan untuk menyuarakan wacana kekerasan terhadap perempuan terlihat bahwa film ini mengantar kita pada wacana kekerasan terhadap perempuan yang berbeda dengan menempatkan persoalan kekerasan sebagai persoalan yang tidak hanya dilihat dari satu aspek saja yakni hukum (normatif). Film ini menyodorkan kepada audiens bahwa wacana kekerasan terhadap anak dan perempuan adalah persoalan yang kompleks, persoalan kemanusiaan. Kekerasan membawa dampak luar biasa pada korban, fisik, psikologis dan sosial seumur hidup. Dalam film ini digambarkan juga perlawanan terhadap dominasi orang tua dan dominasi laki-laki. Bahwa kekerasan sebagai refleksi dari dominasi orang tua menimbulkan penderitaan pada anak, menimbulkan trauma dan dampak psikologis pada anak hingga ia dewasa. Demikian pula dengan dominasi laki-laki pada perempuan membawa permasalahan kompleks dan tidak dapat diselesaikan oleh aparat negara (polisi dan pengadilan).

Kekuatan sutradara perempuan dalam memproduksi film mampu keluar dari mainstream yang selama ini lebih banyak merepresentasikan perempuan dalam stereotip: perempuan selalu kalah dan dikalahkan, cengeng, dan kurang rasional dalam memandang persoalan hidup. Sutradara memberikan ruang pada audiens untuk mendiskusikan bahwa persoalan kekerasan pada perempuan tidak cukup dilihat dari perspektif normatif, hukum, relasi orang tua dan anak, namun juga perspektif perempuan sebagai subyek. Sutradara membawa pe- nonton pada kesadaran bahwa kekerasan pada perempuan adalah kejahatan kemanusiaan yang luar biasa, persoalan manusia, yang harus dilihat dengan "hati" bukan "rasional , hukum dan kepatutan masyarakat".

\section{DAFTAR PUSTAKA}

Baran, J. S., 1999, Introduction to Mass Communication, California, Mayfield Publishing Company.

Baso, Z. A., Aries, T.D.; Haerani, S. dan Rahman, A., 2002, Kekerasan Terhadap Perempuan Menghadang Langkah Perempuan, Yogyakarta: Pusat Studi Kependudukan dan Kebijakan UGM dan Ford Foundation.

Dominick, J. R., 1993, The Dynamics of Mass Communication, United State of America, McGraw-Hill.

Dzuhayatin, S.R. dan Yuarsi, S.E., 2002, Kekerasan Terhadap Perempuan di Ruang Publik, Laporan Penelitian, Yogyakarta: Pusat Studi Kependudukan dan Kebijakan UGM dan Ford Foundation.

Foucault, M., 2009, Pengetahuan dan Metode, Karya-karya Penting Foucault, Yogyakarta: Jalasutra.

Ghassani, H., 2010. Kekerasan Terhadap Perempuan: Analisis Semiotika Film Jamila dan Sang Presiden, Tesis, Semarang : Program Studi Ilmu Komunikasi, FISIP Universitas Diponegoro, Semarang.

Ibrahim, I. S., 2007, Budaya Populer sebagai Komunikasi, Yogyakarta: Jalasutra Jorgensen, Marianne W. \& Phillip, Louise J., 2007. Analisis Wacana, Teori dan Metode, Yogyakarta: Pustaka Pelajar.

Liestianingsih, D., 2003, Peran Gender dalam Iklan Obat Kuat Kuku Bima TL \& Stimultan Hemaviton di Televisi, Laporan Penelitian, Surabaya : LPPM-Universitas Airlangga

2005, Relasi Gender dalam Sinetron Komedi Bajai Bajuri di Trans TV, La- 
poran Penelitian, Surabaya: LPPMUniversitas Airlangga.

Prabasmoro, A. P., 2006, Kajian Budaya Feminis, Tubuh, Sastra dan Budaya Pop, Yogyakarta: Jalasutra.

Sen, Krishna dan Hill, David, T., 2000, Media Budaya dan Politik di Indonesia, Jakarta: ISAI.

Sunarto, 2009, Televisi, Kekerasan \& Perempuan, Jakarta, Kompas Media Nusantara Wood, Julia, T., 2005, Gendered Lives, Communication, Gender \& Culture, Belmont, USA, Thomson, Wadsworth.

Suryandaru, Y. S., (ed), 2002, Potret Kesadaran Gender Orang Media, Laporan Penelitian, Pusat Studi Wanita Universitas Airlangga dan Kementrian Pemberdayaan Perempuan RI.

Srinthil, Media Perempuan dan Multikultural, No. 011, 2007.
Yulianto, V. I., 2007, Pesona Barat, Analisa Kritis-Historis Tentang Kesadaran Warna Kulit di Indonesia, Yogyakarta: Jalasutra.

Udasmoro, W., 2009, "Critical Discource Analysis terhadap Wacana Politik Pluralis Prancis: Mempersoalkan Sentral dan Periferi" dalam Jurnal Leksika, Vol. 3, No. 2 Agustus, p.p. 1-11.

\section{Sumber Lain:}

Jurnal Perempuan, No 61, 2008

Inside Indonesia, No 83, 2005.

www.filmmakers.com.

www.djpp.depkumham.go.id, www.komnasperempuan.or.id www.resources.unpad.ac.id www.elsam.or.id http:/ / rumahfilm.org). 